DOI 10.37491/UNZ.71.15

УДК 347.511

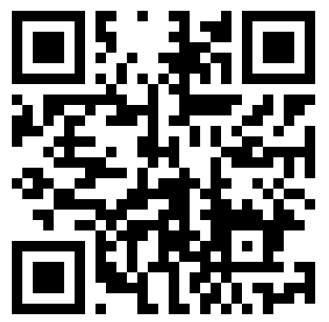

\title{
Світлана ЯКИМЧУК
}

\section{МОДЕЛІ ПРИМУСОВОГО ВИКОНАННЯ СУДОВИХ РІШЕНЬ}

\begin{abstract}
Досліджуються моделі виконання судових рішень як загальні зразки або алгоритли примусового виконання. Проаналізовано декілька класифбікацій моделей примусового виконання - англосаксонського права та романо-германського права; иентралізовані та децентралізовані; публічно-правові несудові; з частковою або повною приватизацією виконавчого провадження та передачею фбнкиій з примусового виконання судових рішень приватнил структурал; з розосередженнял фбункиій з виконання судових рішень між органами суду в особі судових виконавців та органів виконавчої влади.
\end{abstract}

Беручи за основу спосіб організацї профбесії судового виконавия, доцільно всі моделі поділяти на приватноправові, публічноправові та змішані. Так, для приватноправових моделей (Франиія, Нідерланди, Португалія, Бельгія, Люксембург, Словенія, Молдова, Естонія, Латвія, Литва тощо) характернил є те, шо проведення виконавчих дій здійснюеться приватнили судовили виконавияли, які е висококваліфбікованими фбахівияли, отримали університетську освіту в галузі юриспруденції та склали державний кваліфбікаиійний іспит. Вони поєднують статус представників вільної профьесї, тобто на власний розсуд організують свою роботу, а з іншого боку, оскільки держава делегуе їм виконувати фбункиї, щодо виконання судових рішень, - державних посадових осіб. Приватні судові виконавиі призначаються на

\footnotetext{
${ }^{1}$ кандидат юридичних наук,

доцент кафедри цивільного права та процесу,

Хмельницький університет управління та права імені Леоніда Юзькова opermaks@gmail.com,

https://orcid.org/0000-0003-1848-494X
}

(C) Якимчук С. О., 2019 
свої посади органами державної влади шляхом надання їм ліцензіі. У публічно-правових моделях (Німеччина, Швеція, Фінляндія, Австрія, Іспанія, Данія, Італія, Словаччина, Туреччина, Хорватія, Азербайджан, Білорусія, Росія, Таджикистан тощо) виконання судових рішень покладається виключно на посадових осіб державних органів, які можуть мати вищу юридичну освіту та/або бути підготовленими на спеціальних курсах (наведене залежить від того, до складу якого органу належить посадова особа, яка здійснюе виконання). При иьому такими державними органали можуть бути як суди, так $i$ спеціально створені органи прилусового виконання. Залежно від того, посадові особи яких органів зайлаються виконанням судових рішень, всі публічноправові моделі можна поділити на судові (Австрія, Данія, Iспанія), несудові (Фінляндія, Туреччина, Швеція, Білорусія) та змішані (Німеччина, Словаччина, Хорватія). В останніх виконанняли зайлаються посадові особи як судів, так $і$ спеціально створених для иього органів виконавчої влади, колпетенція яких розмежовуеться залежно від способу виконання. Злішані моделі примусового виконання (США, Казахстан) поєднують у собі ознаки приватноправових й публічно-правових. Вони характеризуються тим, шо виконувати судові рішення можуть одночасно органи державної влади і різні приватні особи.

Систему виконання судових рішень слід оиінювати, зважаючи на реальну еббективність виконання судових рішень. При иьому фборли організації діяльності агентів виконання, тобто моделі виконання судових рішень, безпосередньо не визначають проиедури виконавчого провадження, а в умовах низької ебективності виконавчого провадження необхідним і иілком доречним є запровадження змішаної моделі виконання судових рішень, шо $i$ відбулося в Украӥні у 2016 році.

Ключові слова: виконання судових рішень, моделі примусового виконання.

$\Pi_{\text {o }}$ орядок примусового виконання судових рішень має суто національний характер, оскільки історично складається в кожній країні окремо під впливом різних обставин. Крім того, відповідно до традиційних поглядів заходи примусового виконання мають відповідати територіальному принципу [1, с. 56]. Однак, незважаючи на це, в науці робиться спроба систематизувати існуючі національні системи виконавчого провадження, виділивши так звані моделі примусового виконання, які можна розглядати як загальний зразок або схему примусового виконання, де виділяються лише найбільш загальні ознаки побудови системи органів примусового виконання та їх функціонування, які характерні для певної сукупності країн, а особливі, притаманні кожній країні окремо опускаються. При цьому такі авторські класифікації, як і будь-які інші, не є юридично чистими, але водночас дозволяють краще зрозуміти зміст системи примусового провадження, існуючий у кожній країні [2, с. 98], а також виділити переваги та недоліки тіеї чи іншої моделі. Дослідження моделей приму- 
сового виконання дасть можливість краще зрозуміти системи примусового виконання рішень, побачити переваги та недоліки тієї чи іншої моделі, зокрема і на національному рівні, адже в Україні з 2016 року було запроваджено змішану модель примусового провадження.

Дослідженням цих питань займались багато науковців і практиків, такі як: А. Авторгов, В. Комаров, Д. Малешин, О. Сивокозов, В. Ярков, Б. Хесс, О. Верба-Сидор, У. Воробель та багато інших.

Існуе декілька класифікацій моделей примусового виконання. Так, Д. Я. Малешин виходить з того, що традиційно модель виконавчого провадження залежить від типу цивільного процесу. Він відмежовуе виконавче провадження англо-саксонського права від виконавчого провадження романо-германського права, однак риси, притаманні тій чи іншій моделі, не виділяе [3, с. 321-322]. 3 наведеним, на наш погляд, важко погодитися, оскільки системи виконавчого провадження, наприклад, Франції та Німеччини, які належать до країн романо-германського права, істотно відрізняються одна від одної, про що буде зазначено нижче, й взагалі відносяться до різних моделей виконавчого провадження. Слід відмітити, що Д. Я. Малешин також зазначає, що ключовим критерієм розмежування типів виконавчого провадження повинна бути мета цивільного процесу. У одному випадку виконання $е$ частиною цивільного процесу, а в іншому - ні. У першому випадку суд повинен бути ключовим учасником виконавчого провадження, оскільки виконання здійснюеться в цивільній процесуальній формі. В другому випадку роль суду мінімальна, основними учасниками $є$ органи виконавчої влади або взагалі приватні організації [3, с. 321-322]. Однак з виділенням вищезазначеного критерію також важко погодитися, оскільки, як зазначив Свропейський суд з прав людини в рішенні у справі Крутько проти Украӥни (№ 2) провадження в суді та виконавче провадження $є$ відповідно першою та другою стадіями одного провадження. Таким чином, виконавче провадження не має бути відокремлене від судового, і ці обидва провадження мають розглядатися як цілісний процес [4]. Крім того, вищезазначена теза спростовуеться існуючими прикладами систем примусового виконання. Так, у Франції примусовим виконанням, у якій займаються приватні судові виконавці, виконавче провадження традиційно розглядається як частина цивільного процесуального права, як невід'ємна умова доступу громадян до правосуддя (оскільки без реального виконання вимог юрисдикційного акта неможливий практичний захист порушених чи оспорюваних прав, свобод та охоронюваних законом інтересів). Процедура виконання актів судів та інших органів цивільної юрисдикції у Франції входить до складу судочинства [5, с. 44-45].

Б. Хесс пропонуе залежно від того, чи складають органи примусового виконання едину систему, чи існуе декілька систем, що фрункціонують паралельно, поділяти їх на централізовані та децентралізовані. Для централізованих моделей притаманним $є$ те, що виконанням, незалежно від способу стягнення, займаються органи, включені до єдиної системи, а децентралізовані моделі - наявністю декількох органів, повноваження яких у сфері виконання можуть залежати від способу, за допомогою якого 
можна реалізувати рішення. На думку автора, централізовані моделі $є$ більш ефрективні, ніж децентралізовані. Їх переваги грунтуються на низці фракторів: стягувач може негайно розпочати процедуру виконання без будь-якої згоди компетентного органу, виконавець має широкі можливості на отримання інформації про фрінансовий стан боржника, а також доступ до закритих реєстрів; паралельне виконання, як правило, виключається; здебільшого скоординовані зусилля щодо мирного врегулювання $[1$, с. 57 , 71].

Із запропонованою класифікацією, на наш погляд, можна погодитися, оскільки вона дозволяе зрозуміти специфіку систем виконання країн, залежно від особливостей ієрархічної побудови органів виконання, та визначити їх ефективності. Так, до централізованих моделей можна віднести системи примусового виконання Фінляндії, Албанії, Австрії, Бельгії тощо. Наприклад, у Фінляндії в систему органів примусового виконання входять Міністерство юстиції, в якому для цього безпосередньо створено Бюро у справах примусового виконання Департаменту правового управління, начальники управлінь юстиції губернського правління та місцеві підрозділи примусового виконання. При цьому Міністерство юстиції та начальники управлінь юстиції губернського правління є управлінськими органами примусового виконання, безпосереднім виконанням займаються місцеві підрозділи примусового виконання на чолі з повітовим фоогтом [6]. В Албанії для виконання судових рішень створена служба примусового виконання, загальну відповідальність за управління якою несе міністр юстиції. У структуру ціеї Служби входять генеральний директор, що становить центральний рівень, та 29 підрозділів 3 примусового виконання, які знаходяться в судових округах першого ступеня та становлять місцевий рівень організації з загальною чисельністю 112 судових приставів [7, с. 182-183]. В Австрії також функціонуе централізована модель примусового виконання, хоча виконавче провадження знаходиться у віданні судів. Судді за місцезнаходженням боржника або його майна визначають основні параметри виконання, іншу роботу виконують секретарі суду, а судові виконавці, що діють у цій галузі, виконують рішення судів, здійснюючи фрізичні дії, тобто вчиняючи примусові дії, вказані судом, до тих пір, поки постанови не будуть виконані або не стане зрозумілим, що вони не можуть бути виконані [8, с. 52-53]. Систему примусового виконання Бельгії можна віднести до централізованої моделі, незважаючи на те, що судові пристави-виконавці $е$ приватними особами. Вони $е$ единими суб’ектами, які займаються примусовим виконання. Навіть Міністерство фінансів (податків) та місцеві органи влади не мають власних агентів 3 реалізації рішень. Судові пристави мають повноваження в межах того судового округу, в якому були призначені, хоча усередині округу існує конкуренція між ними [9, с. 113-116].

Прикладами децентралізованих моделей е системи примусового виконання Франції, Німеччини, Англії та Уельсу тощо. Так, у Франції приватні судові виконавці користуються монополією на здійснення примусового виконання, крім випадків, коли способом виконання е накладення арешту на заробітну плату [10, с. 173-175]. Судовий виконавець як поса- 
дова особа, яка користується монополією у сфері примусового виконання, повністю незалежний від органів влади у питаннях виконання судових рішень. Над ним немає вищих інстанщій або якої-небудь іншої влади, якщо не рахувати відповідальності за професійні порушення та за дисциплінарні проступки перед відповідною палатою [5, с. 73-76]. У Німеччині виконання судових рішень проводиться, як правило, судовими приставами. До компетенції дільничного суду належить примусове виконання рішень, предметом яких е звернення стягнення на вимоги або інші майнові права. Найбільш розповсюдженим способом виконання таких рішень $\varepsilon$ накладення арешту на суму боргу та переведення його стягувачу. Функціонально ці завдання покладаються частково на суддю, а переважно на правозастосовувача суду. Виконання судових рішень щодо нерухомого майна шляхом примусової реалізації з торгів також належить до компетенції судів та здійснюеться через установи, які ведуть поземельні книги та є одним 3 відділів суду [11, с. 61-66]. Найбільш децентралізована модель примусового виконання існуе в Англії та Уельсі. Так, арешт майна боржника, що знаходиться у третіх осіб, проводиться судами, що ухвалили рішення. Звернення стягнення на майно, засноване на рішенні Високого Суду Лондона, виконуеться шерифами та бейліфрами, які зараз перейменовані в «агентів з виконання». На рівні судів графств судові рішення приводяться до виконання судовими приставами, що знаходяться у складі штату суду. Публічні утворення, такі як Міністерство фінансів та місцеві органи влади, утримують своїх власних виконавців або звертаються до приватних виконавців [12, с. 149-159; 13, с. 270-283]. Зазвичай наводиться також дві основні класифікації моделей примусового виконання судових рішень, запропоновані В. В. Ярковим [14, с. 29-40; 15, с. 118-144] за способом організації професії судового виконавця, а також можливості участі недержавних організацій у виконавчому провадженні та місцем органів та посадових осіб примусового виконання.

За першим критерієм автор усі існуючі моделі поділяе на публічноправові, небюджетні (приватноправові) та змішані. Він вважає, що для публічно-правових моделей притаманним $\epsilon$ те, що судові виконавці та співробітники всіх залучених у процес виконання організацій (торгових, спеціалістів з оцінки тощо) мають перебувати на державній службі, тобто відбувається повне одержавлення всіх сторін виконавчого провадження, відсутність приватної ініціативи під час здійснення окремих видів виконавчих дій. Така організація існуе у Північній Кореї та Кубі. У небюджетних (приватноправових) моделях профресія судового виконавця організована на ліберальних засадах, судовий виконавець $є$ вільним профресіоналом, який самостійно організуе свою діяльність та несе при цьому повну майнову відповідальність за результати своеї роботи. Однак при цьому він не є повністю незалежним, оскільки виконує свої повноваження від імені держави, призначаеться на посаду та діє в межах законодавства, що визначає зміст та характер виконавчих процедур. Інші юридичні профресії, які діють у сфрері виконавчого провадження, пов’язані з реалізацією майна, також здійснюються на приватній основі. Така модель існуе у Франції, Бельгії, Люксембурзі, Нідерландах, Італії, Греції, Литві, Латвії, 
Словенії. Найбільш розповсюдженими, на думку В. В. Яркова, е змішані моделі виконавчого провадження, коли за публічно-правової організації професії судового пристава-виконавця рівною мірою у процес виконання допускаються організації, які діють на різній організаційно-правовій основі, що спеціалізуються на розшуку боржника та його майна, оцінщі, зберіганні та реалізації майна боржника. Вони трапляються у Швеції, Фінляндії, Данії, Німеччині, США, Росії та інших країнах [2, с. 192].

Слід відмітити, що В. В. Ярков як критерій наведеної вище класифікації використовуе «ступінь небюджетної організації». Він виділяе лише дві моделі: небюджетну (приватноправову) та змішану, де при збереженні публічно-правового статусу судового пристава низка функцій у процесі примусового виконання здійснюеться на приватноправовій основі. Хотілося б також підкреслити, що автор займає неоднозначну позицію щодо віднесення системи примусового виконання судових рішень Росії до тіеї чи іншої моделі, оскільки, проводячи класифікацію моделей, він останню наводить як приклад змішаної моделі, а в подальшому зазначае, що "на цей час в Росії система повністю державного виконання» [16, с. 207-209; 17, с. 86-89]. Вбачаеться, що наведена вище класифікація е логічною, однак має певні неузгодженості та недоліки, оскільки, по-перше, незрозумілим залишається те, чим керуеться автор, коли різні за своєю природою системи примусового виконання відносить до одніеї моделі. Так, у Швеції, система примусового виконання якої наводиться як приклад змішаної моделі, виконанням займаеться державний орган - Управління з виконання судових рішень в особі судових приставів [8, с. 40-56]. У Німеччині також примусове виконання може здійснюватися лише державними органами: судовими виконавцями (§ 753 ЦПК), які є державними службовцями, або судами виконавчого провадження (§ 764, 828 ЦПК) [18, с. 288]. Безпосередне звернення до приватних осіб, які б могли виконати судове рішення, не допускається. Інкасо-бюро можуть сприяти реалізації вимог лише на досудовому етапі, тобто до моменту звернення до органів правосуддя i ïx, на наш погляд, не можна відносити до органів примусового виконання судових рішень. Аналогічна ситуація спостерігається й у Фінляндії, Данії [7] та Росії [19], де виконанням займаються державні органи, які створені переважно для цього. Таким чином, у наведених вище країнах органами примусового виконання е державні органи, засновані для виконання судових рішень, і безпосередне звернення до приватних осіб не допускається. У США, навпаки, діюча система виконання судових рішень приватними колекторськими компаніями, діяльність яких регламентуеться Законом «Про чесні методи стягнення боргів», дозволяе здійснювати виконання судових рішень без залучення державних структур. Звернення до державних органів (служби шерифів та маршальської служби) відбувається лише у виняткових випадках, коли ситуація вимагае застосовування авторитету та розширених владних повноважень державних органів [20, с. 32-39; 21, с. 275-291].

По-друге, навряд чи можна "прирівнювати» й відповідно відносити до одніеї моделі системи, в яких органами примусового виконання є лише спеціально створені для цього державні органи, навіть якщо частину сво- 
їх фрункцій після відкриття виконавчого провадження вони можуть делегувати іншим приватним органам та особам, та системи, в яких органами примусового виконання одночасно можуть виступати як державні органи, так і приватні особи. Так, наприклад, відповідно до Федерального закону Російської Федерації «Про виконавче провадження» № 229-ФЗ від 2 жовтня 2007 р. примусове виконання судових актів, актів інших органів і посадових осіб покладаються на Федеральну службу судових виконавців та ïi територіальні органи в особі судових приставів-виконавців [22, с. 67-71]. Натомість Закон Республіки Казахстан «Про виконавче провадження та статус судових виконавців» від 2 квітня 2010 р. передбачае створення інституту приватних судових виконавців, який $е$ альтернативним способом виконання виконавчих документів [23; 24, с. 154-157], тобто одночасно 3 державними судовими виконавцями діють приватні судові виконавці, які виконують свої посадові обов'язки від власного імені та під свою відповідальність.

Наведене, на наш погляд, вимагає під час збереження запропонованої В. В. Ярковим класифікації уточнити ознаки публічно-правової та змішаної моделей виконання судових рішень. Так, особливості публічноправової моделі виконання судових рішень полягають у тому, що з метою примусового виконання судових рішень особа зобов'язана звертатися лише до спеціально створених для цього державних органів примусового виконання, які, у свою чергу, в разі потреби залучають до процесу виконання судових рішень інших суб'єктів, які можуть бути як державними, так і приватними особами. Змішана модель примусового виконання характеризуеться тим, що виконувати судові рішення можуть як спеціально створені для цього органи державної влади, так і різні приватні особи, які діють паралельно з відповідними державними органами.

Друга класифікація моделей, запропонована В. В. Ярковим, грунтується на місці органів та посадових осіб примусового виконання — вони найчастіше працюють або в межах органів судової влади та є посадовими особами судової влади, або виконавчої влади. У першому випадку за судової моделі, працюючи при органах судової влади, судові виконавці є посадовими особами при судах або самі функції примусового виконання покладені на суди. До таких моделей можна віднести систему примусового виконання Німеччини, Данії, Іспанії, Кіпру. В інших країнах органи примусового виконання входять до системи виконавчої влади, як правило, органів юстиції. Наведене характерне для всіх країн, де профресія судового виконавця е ліберальною, а також в Албанії, Словенії, Туреччині, Хорватії, Швеції, більшості країн СНД. У деяких країнах окремі функції виконання доручені нотаріусам, зокрема в Албанії, Хорватії, Іспанії та Естонії [25, с. 470-472].

Вбачається, що запропонована вище класифікація також має низка недоліків. Так, по-перше, вона дає можливість провести розмежування лише між моделями, в яких примусове виконання належить до компетенції державних органів, не враховуючи, що, як зазначалося вище, примусове виконання може здійснюватися й приватними виконавцями, які не належать ані до судової, ані до виконавчої гілок влади. Ця класифікація 
не має також «всеосяжного» характеру, тобто вона не може використовуватися для класифікації всіх існуючих систем примусового виконання та віднесення їх до певної моделі, виходячи із запропонованого критерію. Тому, на наш погляд, вона повинна використовуватися лише для "внутрішньої» класифрікації публічно-правових моделей. По-друге, під час ії формулювання не було взято до уваги, що виконання може проводитися різними органами, які належать як до судової, так і до виконавчої гілок влади. Так, наприклад, у Данії органами примусового виконання є суди та пристави, що працюють у відповідних органах влади. Критерієм розмежування їх компетенції $е$ характер справи, в межах якої проводиться виконання. Приватні вимоги виконуються винятково судами, а вимоги, що стосуються публічних справ, - зазвичай приставами [7, с. 191-192]. Тому, на наш погляд, поряд із судовою та несудовою моделями має виділятися й змішана, в межах якої виконанням займаються різні органи, віднесені до різних гілок влади. Як уже зазначалося, мова йде про «внутрішню» класифікацію лише публічно-правових моделей, то й відповідно їх доцільно називати публічно-правова судова, публічно-правова несудова та публічно-правова змішана моделі примусового виконання.

Слід відмітити, що Б. Хесс проводить дещо схожу з В. В. Ярковим класифікацію, однаквін поєднує обидва критерії, що використовуються російським вченим, та в основу своеї класифікації покладае орган, що здійснюе примусове виконання. Він виділяе чотири моделі примусового виконання. Так, перша модель орієнтована на приватних виконавців, де примусове виконання здійснюють приватні виконавці, які діють як представники держави, але не входять до судової системи (Франція, країни Бенілюксу, Шотландія, Португалія, Нідерланди). Друга модель орієнтована на судове виконання (Австрія, Іспанія, Данія). Автор зазначає, що окремі деталі таких моделей істотно відрізняються. В Австрії виконавче провадження знаходиться в компетенції суду за місцезнаходженням боржника, а вчинюеться на постійній основі судовим виконавцем у самостійному провадженні. В Іспанії за виконання рішення відповідае суддя, який його виніс. Відповідно компетенція іспанського суду не залежить від місця проживання боржника або місцезнаходження його майна, а визначається загальними правилами підсудності. У судово-оріентованих системах звернення стягнення на рухоме майно здійснюеться приватними приставами, або agentes judiciales, які є службовцями в штаті суду. Третя модель е змішаною (Німеччина, Англія), в якій виконавче провадження частково здійснюеться приватними приставами або шерифами (особливо стягнення рухомого майна), в той час як арешт майна боржника, що знаходиться у третіх осіб, санкціонуеться судом. Для четвертої моделі характерним е те, що примусове виконання здійснюють адміністративні органи, що діють повністю незалежно від судів (Швеція, Фінляндія) [1, с. 53-76; 26, с. 259-266].

Запропонована Б. Хессом класифрікація також не позбавлена недоліків, оскільки в її межах не знайшли, по-перше, відображення моделі, в яких виконання проводиться різними державними органами, які належать як до судової, так і до інших гілок влади. Наведене, як уже зазнача- 
лося, має місце в Данії, яка автором, на наш погляд, помилково віднесена до моделі, орієнтованій на судове виконання. Крім того, аналогічне судження можна зробити й щодо Іспанії, де примусове виконання судових актів, а також актів інших органів віднесено до кола фрункцій, що покладаються на суди. Водночас законодавство передбачає можливість здійснення певних виконавчих дій особами та організаціями, що не входять до судової системи. Так, наприклад, «позасудовим провадженням щодо звернення стягнення на заставлене майно» $е$ примусова реалізація прав заставодержателя, яку проводить нотаріус, хоча щодо дій останнього зберігається судовий контроль. Яскравим прикладом такої змішаної моделі $є$ виконавче провадження Словаччини, де органами, уповноваженими виконувати судові та інші рішення, є районні суди та судові виконавці. При цьому останні призначаються Міністром юстиції та не є працівниками суду. Їх мандат не обмежений юрисдикцією судового округу, оскільки вони можуть здійснювати свої профресійні фрункцї на всій території. Кредитори самі обирають, чи звертатися їм до суду для виконання судового рішення відповідно до Цивільного процесуального кодексу, або звертатися до судового виконавця, який діє відповідно до Виконавчого кодексу, призначається на посаду міністром юстиції та не є працівником суду [7, с. 169-243].

По-друге, системи, в яких примусове виконання віднесено до повноважень державних органів, чи то суди, чи то спеціально створені органи виконавчої влади, мають багато спільних рис (фінансування, відповідальність за проведення виконавчих дій тощо), тому більш логічним є віднесення їх до одніеї публічно-правової моделі, як це певною мірою пропонував В. В. Ярков, з метою виділення спільних ознак, які відрізняють їх від приватноправових моделей, визначенням переваг та недоліків. У подальшому, як уже зазначалося, системи, віднесені до публічно-правової моделі, підлягають класифікації залежно від приналежності до тіеї чи іншої гілки влади органу, що здійснюе примусове виконання.

На наш погляд, беручи за основу спосіб організації профресії судового виконавця доцільно всі моделі поділяти на приватноправові, публічноправові та змішані. Аналіз національних систем примусового виконання дає можливість виділити такі ознаки вищезазначених моделей. Так, для приватноправових моделей (Франція, Нідерланди, Португалія, Бельгія, Люксембург, Словенія, Молдова, Естонія, Латвія, Литва тощо) характерним $е$ те, що проведення виконавчих дій здійснюеться приватними судовими виконавцями, які є висококваліфрікованими фрахівцями, отримали університетську освіту в галузі юриспруденції та склали державний кваліфрікаційний іспит. Вони поєднують в собі статус представників вільної профресії, тобто на власний розсуд організують свою роботу, а з іншого боку, оскільки держава делегуе їм виконувати фрункції, щодо виконання судових рішень, - державних посадових осіб. Приватні судові виконавці призначаються на свої посади органами державної влади шляхом надання їм ліцензії. Фінансування діяльності таких судових виконавців здійснюеться за рахунок коштів «приватних» осіб, тобто учасників виконавчого провадження, які зобов'язані нести витрати, пов'язані з виконанням судових рішень, хоча їх розміри встановлюються законами або рішеннями 
центральних органів державної влади. Вони самостійно організують свою діяльність, тобто орендують офіс, наймають співробітників, вирішують питання, щодо об'єднання з іншими приватними судовими виконавцями в бюро, однак під час проведення виконавчих дій зобов'язані дотримуватися законів та інших нормативно-правових актів, які встановлюють порядок виконання. Їх повноваження можуть визначатися територією певного судового округу, в межах якого вони призначені (Бельгія) [9, с. 114], що не виключае конкуренції усередині, або поширюватися в усіх чи окремих випадках на територію всієї країни (Молдова) [27, с. 147-151]. Стягувачі мають право обирати, до якого приватного судового виконавця звертатися, враховуючи встановлені обмеження, наприклад, щодо території, на якій останні мають право діяти. Крім того, в деяких країнах допускаеться заміна приватного судового виконавця за ініціативою стягувача, якщо останній неналежним чином виконуе судове рішення (Португалія) [28, с. 203]. Під час проведення виконавчих дій приватні судові виконавці є незалежними та підкорюються лише законові, хоча проведення окремих виконавчих дій має санкціонуватися суддею. Їх діяльність контролюеться органами, що здійснили призначення, шляхом проведення перевірок, а також спеціалізованими профресійними організаціями й судом. Приватні судові виконавці несуть повну матеріальну відповідальність за наслідки вчинення або не вчинення виконавчих дій.

У публічно-правових моделях (Німеччина, Швеція, Фінляндія, Австрія, Іспанія, Данія, Італія, Словаччина, Туреччина, Хорватія, Азербайджан, Білорусія, Росія, Таджикистан тощо) виконання судових рішень покладається виключно на посадових осіб державних органів, які можуть мати вищу юридичну освіту та/або бути підготовленими на спеціальних курсах (наведене залежить від того, до складу якого органу належить посадова особа, яка здійснюе виконання). Такими державними органами можуть бути як суди, так і спеціально створені органи примусового виконання. У цих моделях судові виконавці мають право у випадках, встановлених у національному законодавстві, делегувати проведення окремих виконавчих дій (розшук боржника та його майна, оцінка, збереження та реалізація майна, проведення аукціонів тощо) іншим суб'єктам, що можуть діяти на різній організаційно-правовій основі. Як слушно зазначив I. М. Колядко, цю модель можна охарактеризувати як таку, що «заснована на принципах державної служби, в яку упроваджуються приватноправові елементи» [29, с. 244]. Фінансування діяльності таких виконавців здійснюеться за рахунок коштів державних бюджетів, що не виключае можливості додаткового фінансування й за рахунок учасників виконавчого провадження. Судові виконавці можуть самостійно організовувати свою роботу (утримання офрісів, наймання та оплата праці співробітників тощо) в межах виділених для цього коштів (Німеччина) [30, с. 57; 22, с. 67] або працювати в складі відповідних державних органів, в яких на рівні чинного законодавства визначена кількість працівників, їх посадові обов'язки тощо. Діяльність судового виконавця зазвичай обмежуеться територією певного адміністративного округу. Контроль за діями судових виконавців здійснюеться начальником відповідного органу, а також судом, до якого 
можуть бути оскаржені рішення, дії чи бездіяльність судового виконавця. Шкода, спричинена неправомірними діями або бездіяльністю судових виконавців під час проведення виконання, відшкодовуеться державою.

Залежно від того, посадові особи яких органів займаються виконанням судових рішень усі публічно-правові моделі можна поділити на судові (Австрія, Данія, Іспанія), несудові (Фінляндія, Туреччина, Швеція, Білорусія) та змішані (Німеччина, Словаччина, Хорватія). В останніх виконанням займаються посадові особи як судів, так і спеціально створених для цього органів виконавчої влади, компетенція яких розмежовуеться залежно від способу виконання.

Змішані моделі примусового виконання (США, Казахстан) поєднують у собі ознаки приватно-правових і публічно-правових. Вони характеризуються тим, що виконувати судові рішення можуть одночасно органи державної влади і різні приватні особи. Їх компетенція може розмежовуватися залежно від способу виконання або вони можуть діяти паралельно, й стягувач має право самостійно обирати, до якого органу примусового виконання звертатися, тобто приватні судові виконавці є альтернативою державним судовим виконавцям (Казахстан) [24, с. 154-157]. Рівень кваліфрікації судових виконавців, фінансування їх діяльності, контроль за їхньою діяльністю залежить від того, чи є судовий виконавець посадовою особою державного органу чи приватною особою.

Слід відмітити, що кожна описана вище модель примусового виконання має як недоліки, так і переваги. Так, до переваг публічно-правової моделі в літературі відносять те, що статус державного службовця забезпечуе державному виконавцю можливість наділення публічною владою та владними повноваженнями, доступ до закритої інформації, а також взаємодію в процесі роботи з іншими державними органами, універсальність його компетенції [25, с. 465-504]. Серед недоліків можна виділити незацікавленість судових виконавців у результатах своєї роботи, оскільки оплата їх праці не пов'язана з обсягом виконаних рішень та розміром стягнених сум й відповідно тривале та малоефективне проведення виконавчих дій, недостатне фрінансування з боку держави тощо.

Перевагами ж небюджетної (приватноправової) моделі є мотивація виконавців та більша націленість на результативність, оскільки оплата їх послуг залежить від обсягу та якості здійснених виконавчих дій; особиста майнова відповідальність за допущені помилки; відсутність державного фрінансування; отримання державою доходу від діяльності не бюджетних виконавців у вигляді податків; самостійна організація роботи виконавцями; можливість публічного контролю через органи юстиції, а також організації, створені самими виконавцями [2, с. 108; 31; 32, с. 101-121], відсутність корупщії [24, с. 154-157]. Ця модель має переваги й для тих, на чию користь виконуеться рішення, оскільки вони отримують можливість самостійно обирати судових приставів, віддаючи переваги тим, хто зможе швидко та ефрективно добитися виконання судового рішення [30, с. 58]. У той же час серед недоліків цієї моделі виділяють необхідність стимулювання приватних виконавців на роботу, щодо проведення стягнення невеликих сум; ускладнення взаємовідносин з іншими юридичними орга- 
нами, необхідних для отримання інформації; утрата оперативного контролю за діяльністю приватних виконавців; виникнення проблем щодо «обслуговування» чисельних малонаселених регіонів, де приватний виконавець навряд чи зможе працювати на умовах самоокупності; подорожчання юридичної індраструктури [33, с. 268; 32, с. 110-111], зловживання з боку судових приставів-виконавців, оскільки стимулом їхньої діяльності буде прагнення до отримання якомога більшого прибутку; можлива криміналізація цього сегменту правової діяльності [34, с. 498].

Усі наявні в літературі пропозиції щодо редормування системи примусового виконання можна звести до трьох підходів. Перший передбачає подальший розвиток публічно-правової несудової моделі виконання судових рішень шляхом посилення іï правоохоронної складової та подальшого відокремлення аж до повного відділення від міністерства юстиції служби судових приставів. Другий підхід пов'язаний з частковою або повною приватизацією виконавчого провадження та передачею фрункцій 3 примусового виконання судових рішень приватним структурам. Третій підхід орієнтований на розосередження функцій 3 виконання судових рішень між органами суду в особі судових приставів та органів виконавчої влади [35, с. 91-112]. Другий підхід є найпоширенішим. Однак, як слушно зазначав А. Узелач, приватизація в чистому вигляді неможлива, оскільки фрункціонування приватної системи виконання багато в чому залежить від належного регулювання та контролю з боку держави. Вона має як переваги, так і низку ризиків порівняно з виконанням, заснованим на державній моделі примусу [32, с. 101-121]. Крім того, під час проведення реформ необхідно враховувати національні особливості та готовність системи до кардинальних змін.

Аналіз системи примусового виконання України до червня 2016 року давав можливість віднести їі до публічно-правової моделі. Так, примусове виконання рішень покладалось на державну виконавчу службу, яка входила до системи органів Міністерства юстиції України, в особі державних виконавців. Їх діяльність фінансувалась за рахунок коштів Державного бюджету України, а також коштів виконавчого провадження, тобто виконавчого збору, що стягувався з боржника в разі невиконання останнім вимог державного виконавця в добровільному порядку. Інші органи, установи, організації й посадові особи могли провадити окремі виконавчі дії на вимогу чи за дорученням державного виконавця внаслідок обов'язковості його вимог, однак не відносились до органів примусового виконання. Державні виконавці діяли за територіальним принципом, тобто їх повноваження поширювалось лише не певну територію. Контроль за їх діяльністю здійснювався начальником відповідної державної виконавчої служби, а також судом. Шкода, заподіяна державним виконавцем фрізичним чи юридичним особам під час виконання рішень, підлягала відшкодуванню за рахунок держави.

Система примусового виконання, яка фрункціонувала в Україні до червня 2016 року, не була ефективною. Крім того, цей висновок підтверджувався й статистичною інформацією. Так, наприклад, у I півріччі 2011 році, згідно з даними Державної виконавчої служби України, приму- 
совому виконанню підлягало 3 млн 922,4 тис. виконавчих документів, виданих на підставі судових рішень загальних судів. Залишилися невиконаними 2 млн 397,3 тис. виконавчих документів, або 61,1 \% від тих, що підлягали примусовому виконанню. Також примусовому виконанню підлягало 187 тис. виконавчих документів, виданих на підставі судових рішень господарських судів; із них залишилися невиконаними 131,9 тис. таких документів, або 70,5 \%. Порівняно з такими даними у 2013 році надійшло 5311607 виконавчих документів, відмовлено у відкритті виконачого провадження - 561 129, підлягало примусовому виконанню виконавчих документів - 7723746 , але усього завершено виконанням 4754528 документів. Аналогічна ситуація з виконанням судових рішень спостерігалась і в наступні роки - 2014, 2015 [36]. Наведене вимагало підвищення ефективності системи примусового виконання, адже така низька ефективність реального поновлення прав осіб негативно впиває на економічний розвиток держави, зокрема зменшуеться кількість іноземних інвестицій та зростає ціна кредитів від іноземних банків [37, с. 87].

Ще задовго до запровадження змішаної моделі примусового виконання в Україні професор Комаров В'ячеслав Васильович відмічав у своїх працях про необхідність та актуальність проблем пошуку нових моделей виконання судових рішень та виконавчого провадження, адже, на його думку, ключовим питанням для здійснення справедливого судочинства $€$ ефективність виконання судових рішень. Відповідно до процесуального законодавства та прецедентної практики Європейського суду 3 прав людини виконання судових рішень $є$ частиною судового розгляду. У зв'язку з цим, незважаючи на різні зміни у останні роки процесуального законодавства, законодавства про державну виконавчу службу та виконавче провадження пошук потрібної моделі примусового виконання судових рішень був необхідним для здійснення справедливого судочинства в Україні [38, с. 6].

А. Авторгов стверджував, що інститут приватних виконавців треба було вводити ще 10-15 років тому, а не чекати, доки ситуація стане критичною [39], з чим повністю погоджуемось.

Ситуацію, яка склалася з приводу виконання судових рішень, могло покращити введення в дію Закону України «Про органи та осіб, які здійснюють примусове виконання судових рішень і рішень інших органів» $\mathrm{i}$ Закону України «Про виконавче провадження», які Верховна Рада України прийняла 2 червня 2016 р. Запровадження інституту приватних виконавців сприяло переходу України від публічно-правової моделі примусового виконання до змішаної моделі, яка поєднала елементи публічноправової та приватноправової моделей, тобто під час збереження всіх повноважень органів державної виконавчої служби виконувати судові рішення отримали право й приватні виконавці. Останні діють, як альтернативна система примусового виконання, тобто стягувач може обирати, чи звертатися йому до державної виконавчої служби, чи до приватних виконавців. Така ж модель примусового виконання судових рішень у Казахстані. Приватні виконавці мають такі самі повноваження, як і державні виконавці з деякими винятками. Наприклад, як виключна компетен- 
ція державних виконавців залишається виконання: - судових рішень, боржником за якими виступає держава, державні органи, Національний банк України, органи місцевого самоврядування, їх посадові особи, державні та комунальні підприемства, установи, організації, юридичні особи, частка держави у статутному капіталі яких перевищуе 25 відсотків та/або які фрінансуються виключно за кошти державного або місцевого бюджету; - судових рішень за якими держава та їі органи також є стягувачами; судових рішень адміністративних судів та рішень ЄСПЛ; - судових рішень, які передбачають вчинення дій щодо майна державної чи комунальної власності; - судових рішень, за якими боржником є юридична особа, примусова реалізація майна якої заборонена відповідно до закону; судових рішень про відібрання й передання дитини, встановлення побачення з нею або усунення перешкод у побаченні з дитиною, а також коли боржниками є діти або фізичні особи, які визнані недіездатними чи цивільна дієздатність яких обмежена; - судових рішень щодо конфіскації майна, про вселення та виселення фрізичних осіб та деякі інші [40, с. 542].

Вимоги до приватних виконавців закріплені в Законі. Так, наприклад, приватним виконавцем може стати громадянин України, який досяг 25 років, має вищу юридичну освіту не нижче другого рівня, володіє державною мовою, має стаж роботи в галузі права після отримання відповідного диплома не менше двох років та склав кваліфікаційний іспит. Не може стати приватним виконавцем особа, яка не відповідає вказаним вимогам, визнана судом обмеженою в цивільній дієздатності або недієздатною, яка має не зняту або не погашену в установленому законом порядку судимість, яка вчинила корупційне правопорушення або порушення, пов'язане з корупцією, - протягом трьох років з дня вчинення, якій за порушення вимог законодавства анульовано свідоцтво про право на зайняття нотаріальною чи адвокатською діяльністю або діяльністю арбітражного керуючого (розпорядника майна, керуючого санацією, ліквідатора), яку позбавлено права на здійснення діяльності приватного виконавця, - протягом трьох років з дня прийняття відповідного рішення, яка звільнена 3 посади судді, прокурора, працівника правоохоронного органу, 3 державної служби або служби в органах місцевого самоврядування у зв'язку з притягненням до дисциплінарної відповідальності, - протягом трьох років з дня звільнення. Приватний виконавець під час здійснення своеї діяльності не може займатися іншою оплачуваною (крім викладацької, наукової і творчої діяльності, діяльності арбітражного керуючого (розпорядника майна, керуючого санацією, ліквідатора), інструкторської та суддівської практики зі спорту та роботи в органах Асоціації приватних виконавців України) або підприемницькою діяльністю.

Приватні виконавці повинні мати робоче місце в межах виконавчого округу, який визначений у Сдиному реєстрі приватних виконавців України. Приватні виконавці повинні самостійно вирішувати питання щодо оренди та облаштування приміщення, відповідно до вимог, встановлених у чинному законодавстві, наймання співробітників тощо. Їх діяльність має здійснюватися з додержанням вимог, встановлених для проведення виконавчих дій, тобто на них поширюеться Закон України «Про 
виконавче провадження». Розмір основної винагороди приватного виконавця встановлюеться Кабінетом Міністрів України. Контроль за їхньою діяльністю здійснюе Міністерство юстиції України шляхом проведення періодичних планових та позапланових перевірок, Рада приватних виконавців України, а також суд у разі оскарження їх рішень, дій чи бездіяльності. У разі, якщо в результаті проведеної перевірки будуть виявлені порушення вимог чинного законодавства, приватного виконавця може бути притягнуто до дисциплінарної відповідальності. Приватний виконавець несе за свої рішення, дії чи бездіяльність та завдану третім особам шкоду цивільно-правову, адміністративну чи кримінальну відповідальність у порядку та обсягах, установлених законом, а також дисциплінарну відповідальність у порядку, встановленому законом [41, с. 535].

Слід констатувати, що ми поділяемо думку, що сама по собі зміна організаційної основи діяльності судового пристава 3 державного на небюджетну може надати лише незначний ефект [16, с. 219]. Едективність системи примусового виконання залежить не лише від способу організащії профресії судового виконавця, а й від поінформованості останнього про активи боржника, що безпосередньо впливає на результативність проведення виконавчих дій $[1$, с. 72$]$. Виділяють декілька способів отримання такої інформації: по-перше, розкриття інформації боржником добровільно або на підставі розпорядження; по-друге, розширення можливості або органів з виконання судових рішень, або кредитора для отримання інформації від третіх осіб; по-трете, використання органами з виконання судового рішення закритих записів, що е в розпорядженні державних органів (наприклад, податковий орган) [8, с. 46-49; 35, с. 91-112]. В Україні чинне процесуальне законодавство містить обов'язок боржника подати виконавцю декларацію про доходи і майно, яким він володіє, про свої рахунки в банках чи інших фрінансових установах, про майно, яке перебуває в заставі (в іпотеці) чи в інших осіб та відповідальність за його невиконання розкрити інформацію про свої активи. Однак, у національній правовій системі не створені електронні реєстри, до яких би державний та приватний виконавець мав би вільний доступ й з яких він міг би отримати інформацію, необхідну для проведення виконавчих дій, про боржника та його активи. Існуюча система «документальних запитів інформації» у відповідних повноважних органів (банківських установ, податкових служб, пенсійного фонду тощо) ускладнюе та уповільнюе виконання.

У зв'язку з наведеним, вбачається, що необхідно внести зміни до чинного законодавства, якими виконавцям буде наданий вільний доступ до існуючих реєстрів, у яких може міститися інформація про боржника та його активи. Такий доступ повинен бути в електронному вигляді в режимі on-line.

На наш погляд, зміна моделі примусового виконання з публічноправової на змішану, а також запровадження заходів щодо «забезпеченості» виконавців необхідною інформацію має позитивно позначитися на виконавчому провадженні.

Так, можна навести приклад перших результатів від запровадження змішаної моделі примусового виконання судових рішень в Україні. 
Лише за перше півріччя 2019 року приватними виконавцями стягнуто боргів на суму 1,3 млрд гривень, а відсоток виконаних рішень із запровадженням інституту приватних виконавців збільшився з $6 \%$ у 2017 році до 18 \% у 2018 році. У середньому приватний виконавець повернув у першому півріччі 2019 року суму коштів стягувачам, шляхом реалізації майна боржників у 22 рази більшу, ніж державний виконавець [42].

I хоча дані результати можна назвати певним позитивним моментом на шляху до виконання рішень суду і реального захисту порушених, невизнаних або оспорюваних прав, свобод чи інтересів фрізичних осіб, юридичних осіб, а також держави Однак Україні потрібно ще багато зусиль докласти, щоб досягнути 100 \% виконання всіх прийнятих судових рішень.

\section{Список використаних джерел}

1. Хесс Б. Системы принудительного исполнения. Исполнительное производство: традииии и рефборлы / пер. с англ. под ред. Р. Ван Рее и др. М. : Инфотропик Медиа, 2011. С. 53-76.

2. Оптимизация гражданского правосудия России / под ред. В. В. Яркова. М. : Волтерс Клувер, 2007. 192 с.

3. Малешин Д. Я. Гражданская процессуальная система России. М. : Статут, 2011. $496 \mathrm{c.}$

4. Справа «Крутько проти України» (№ 2) (Заява № 33930/05) : Рішення Свропейського суду з прав людини від 27.11.2008. Верховна Рада Украӥни. Законодавство Украӥни. URL : http://bit.ly/33b9zCz.

5. Кузнецов Е. Н. Исполнительное производство Франции. С.-Пб. : Изд. Дом С.-Петерб. гос. ун-та, 2005. 280 с.

6. Хонгель Ю. Организационная структура и задачи службы принудительного исполнения в Финляндии. Исполнительное производство в Финляндии и России: взгляды. OIKEUSMINISTERIŐ: Helsinki, 2004. URL : http://bit.ly/39XAbtr.

7. Чугунова Е. И., Ереленко М. С. К вопросу об эффрективности исполнения судебных решений по гражданским делам (по материалам 24-й конференции Министров юстиции стран Европы). Защита прав и законных интересов граждан и организаций: матер. Межд. науч.практ. конф. Сочи : Кубан. гос. ун-т, 2002. Ч. I. С. 169-243.

8. Эрлих Ч. «Рабочие инструменты» судебных приставов-исполнителей: обеспечение эффективности исполнительного производства с помощью интегрированных информационных систем. Эфббективность принудительного исполнения судебньх решений и актов других органов : сб. матер. Межд. науч.-практ. конф. (г. Казань, Казан. (Приволжский) федерал. ун-тет, 8-11 июня 2011 г.) / отв. ред. А. О. Парфенчиков и Д. Х. Валеев. М., 2011. С. 40-56.

9. Шмити М. Меры принудительного исполнения, применяемые в Бельгии. Эфббективность принудительного исполнения судебньх решений и актов других органов : сб. матер. Межд. науч.-практ. конф. (г. Казань, Казан. (Приволжский) федерал. ун-тет, 8-11 июня 2011 г.) / отв. ред. А. О. Парфенчиков и Д. Х. Валеев. М. : Статут, 2011. С. 113-118.

10. Шардон М. Принудительное исполнение во Франции: обзора законодательства и практики. Исполнительное производство: традиции и рефбормы / под ред. Р. Ван Рее и др. М. : Инфотропик Медиа, 2011. C. $173-182$. 
11. Франтииох П. Основы немецкого права в области исполнения судебных решений. Эфббективность принудительного исполнения судебных решений и актов других органов : сб. матер. Межд. науч.-практ. конф. (г. Казань, Казан. (Приволжский) федерал. ун-тет, 8-11 июня 2011 г.) / отв. ред. А. О. Парфенчиков и Д. Х. Валеев. М. : Статут, 2011. C. 61-66.

12. Эндрюс Н., Тернер Р. Системы принудительного исполнения судебных решений по гражданским делам. Исполнительное производство: традиции и рефборлы / под ред. Р. Ван Рее и др. М. : Инфотропик Медиа, 2011. С. 149-159.

13. Меню Б. Законы и процедуры, регулирующие исполнение судебных решений во Франции. Защита прав и законных интересов граждан и организаций : матер. Межд. науч.-практ. конф. Сочи : Кубан. гос. ун-т, 2002. Ч. I. С. 270-283.

14. Ярков В. В., Устьянцева С. Е. Конщепция развития системы исполнительного законодательства и Службы судебных приставов Российской Федерации (краткие тезисы). Арбитражный и гражданский процесс. 2001. № 8. C. 29-40.

15. Ярков В. В. Концепция развития системы исполнительного законодательства и службы судебных приставов Российской Федерации (основные тезисы). Проблель зашиты прав и законных интересов граждан и организащий : матер. Межд. науч.-практ. конф. (КраснодарСочи, 23-26 мая 2002 г.). Ч. 1. Сочи, 2002. С. 118-144.

16. Ярков В. В. Отдельные направления развития исполнительного производства в государствах-членах Международного союза судебных исполнителей. Европейский гражданский процесс и исполнительное производство : сб. матер. Межд. науч.-практ. конф. (г. Казань, Казан. (Приволжский) федер. ун-тет, 25 марта 2011 г.) / отв. ред. Д. Х. Валеев. М., 2012. С. 204-224.

17. Исаенкова О. В., Шерстюк В. М., Ярков В. В. Концепция исполнительного кодекса Российской Федерации (краткие тезисы). Защита прав и законных интересов граждан и организаций: матер. Межд. науч.-практ. конф. Сочи : Кубан. гос. ун-тет, 2002. Ч. 1. С. 86-89.

18. Гражданское процессуальное уложение Германии (Deutsche Zivilprozessordnung mit Einführungsgesetz): Вводный Закон к Гражданскому процессуальному уложению: пер. с нем. В. Бергман, введ., сост. М., 2006. 388 c.

19. Об исполнительном производстве: Федеральный закон Российской Федерации от 02.10.2007 г. № 229-Ф3. КонсультантПлюс. URL : http://bit.ly/2U5FVdA.

20. Артемьева Ю. А. Исполнительное производство в США. Эфббективность принудительного исполнения судебных решений и актов других органов : сб. матер. Межд. науч.-практ. конф. (г. Казань, Казан. (Приволжский) федерал. ун-тет, 8-11 июня 2011 г.) / отв. ред. А. О. Парфенчиков и Д. Х. Валеев. М. : Статут, 2011. С. 32-39.

21. Пайич Н. Приведение в исполнение судебных решений в Соединенных Штатах Америки. Исполнительное производство: традиции и рефборлы / под ред. Р. Ван Рее и др. М. : Инфотропик Медиа, 2011. C. 275-291.

22. Цедель $A$. Об эффрективности принудительного исполнения в Германии. Эфбфективность принудительного исполнения судебных решений и актов других органов : сб. матер. Межд. науч.-практ. конф. 
(г. Казань, Казан. (Приволжский) федерал. ун-тет, 8-11 июня 2011 г.) / отв. ред. А. О. Парфенчиков и Д. Х. Валеев. М. : Статут, 2011. С. 67-71.

23. Об исполнительном производстве и статусе судебных исполнителей : Закон Республики Казахстан от 02.04.2010 г. Юрист - Параграфб Online. URL : http://bit.ly/3aWsS5j.

24. Ким Г. В. Система исполнения судебных актов в Республике Казахстан. Эфббективность принудительного исполнения судебных решений и актов других органов : сб. матер. Междунар. науч.-практ. конф. (г. Казань, Казан. (Приволжский) федерал. ун-тет, 8-11 июня 2011 г.) / отв. ред. А. О. Парфенчиков и Д. Х. Валеев. М. : Статут, 2011. С. 154-157.

25. Ярков В. В. Основные мировые системы принудительного исполнения. Проблемные вопросы гражданского и арбитражного процессов / под ред. Л. Ф. Лесницкой, М. А. Рожковой. М., 2008. С. 465-504.

26. Гуреев В. А. Законодательное регулирование исполнительного производства в Финляндии в контексте отечественных правовых реалий. Европейский гражданский процесс и исполнительное производство : сб. матер. Межд. науч.-практ. конф. (г. Казань, Казан. (Приволжский) федер. ун-тет, 25 марта 2011 г.) / отв. ред. Д. Х. Валеев. М., 2012. C. 259-266.

27. Талмач Р. Развитие Исполнительного производства в Республике Молдова. Эфббективность принудительного исполнения судебных решений и актов других органов : сб. матер. Межд. науч.-практ. конф. (г. Казань, Казан. (Приволжский) федерал. ун-тет, 8-11 июня 2011 г.) / отв. ред. А. О. Парфенчиков и Д. Х. Валеев. М. : Статут, 2011. С. 144-153.

28. Лоуренсо П. М. Новые законодательные положения декрета-закона от 20 ноября 2008 г. № 226/2208: усиление роли португальского агента по исполнению и создание Комиссии по эффективности исполнительного производства. Европейский гражданский процесс и исполнительное производство: сб. матер. Межд. науч.-практ. конф. (г. Казань, Казан. (Приволжский) федер. ун-тет, 25 марта 2011 г.) / отв. ред. Д. Х. Валеев. М., 2012. С. 194-204.

29. Колядко И. Н. О путях повышения әффективности исполнения судебных постановлений в Республике Беларусь. Европейский гражданский процесс и исполнительное производство : сб. матер. Межд. науч.-практ. конф. (г. Казань, Казан. (Приволжский) федер. ун-тет, 25 марта 2011 г.) / отв. ред. Д. Х. Валеев. М., 2012. С. 240-251.

30. Неттерсхайл $Г$. Й. Актуальные тенденции в области реформирования системы деятельности судебных приставов. Эфббективность принудительного исполнения судебных решений и актов других органов : сб. матер. Межд. науч.-практ. конф. (г. Казань, Казан. (Приволжский) федерал. ун-тет, 8-11 июня 2011 г.) / отв. ред. А. О. Парфенчиков и Д. Х. Валеев. М. : Статут, 2011. С. 57-61.

31. Улетова Г. Д. Перспективы института частных судебных приставовисполнителей в России [17.11.2015]. Юридический центр CENTERBEREG. URL : http://bit.ly/38MQcAX.

32. Узелач A. Приватизация органов принудительного исполнения шаг вперед для стран переходного периода? Исполнительное производство: традииии и рефборлы / под ред. Р. Ван Рее и др. М. : Инфотропик Медиа, 2011. С. 101-121.

33. Ярков В. В. Исполнительное производство в России: краткий обзор. Исполнительное производство: традииии и ребборлы / под ред. Р. Ван Рее и др. М. : Инфотропик Медиа, 2011. С. 259-269. 
34. Улетова Г. Д., Малиновский О. Н. Исполнительное производство России и проблема создания альтернативной системы исполнения судебных актов. Кониепиия развития судебной систелы и систелы добровольного и принудительного исполнения решений Конституиионного Суда РФ, судов общей юрисдикиии, арбитражньх, третейских судов и Европейского суда по правам человека : сб. науч. статей. Краснодар. С.-Пб., 2007. С. 489-508.

35. Аутдехааг Й. Полномочия приставов в области оперативно-розыскной деятельности: передовой европейский опыт. Эфббекттивность принудительного исполнения судебньх решений и актов других органов: сб. матер. Межд. науч.-практ. конф. (г. Казань, Казан. (Приволжский) федерал. ун-тет, 8-11 июня 2011 г.) / отв. ред. А. О. Парфенчиков и Д. Х. Валеев. М. : Статут, 2011. С. 91-112.

36. Аналіз роботи судів загальної юрисдикції. Віадук-Телекол. URL : http://bit.ly/2w4hhlD.

37. Верба-Сидор О. Б., Воробель У. Б. Інститут приватних виконавців в Україні: пропозиції щодо вдосконалення правового регулювання. $\mathrm{Ha}$ уковий вісник Львівського державного університету внутрішніх справ. 2016. № 1. C. 86-94.

38. Проблеми теорії та практики цивільного судочинства / за заг. ред. В. В. Комарова. Х. : Харків юридичний, 2008. 928 с.

39. Авторгов $A$. Судові рішення, що не виконуються на практиці нічого не варті (29.11.2017). Андрій Авторгов. URL : http://bit.ly/3aRLKSU.

40. Про виконавче провадження: Закон України від 02.06 .2016 p. № 1404-VIII. Відолості Верховної Ради України. 2016. № 30. Ст. 542.

41. Про органи та осіб, які здійснюють примусове виконання судових рішень і рішень інших органів: Закон України від 02.06.2016 р. № 1403-VIII. Відомості Верховної Ради України. 2016. № 29. Ст. 535.

42. Сивокозов O. Інститут приватного виконання в Україні: досягнення та виклики. USAID New Justice Program. URL : http://bit.ly/2UeBkWT.

Надійшла до редакції 13.09.2019

\section{Svitlana YAKYMCHUK}

Leonid Yuzkov Khmelnytskyi University of Management and Law

\section{Models of Enforcement of Court Decisions}

Models of performance of judgments as general models, or algorithms of compulsory enforcement are investigated. Several classifications of models of compulsory enforcement exist - the Anglo-Saxon law and the Romano-German law are analysed; centralized and decentralized; public non-judicial; with partial or full privatization of enforcement proceeding and transfer of function on compulsory performance of judgments to private structures; with dispersal of functions on implementation of judgments between bodies of court represented by bailiffs and executive authorities. It is expedient to divide all models into private-law, public and mixed on the basis of the organization of a profession of a bailiff.

So, under private-law models (France, the Netherlands, Portugal, Belgium, Luxembourg, Slovenia, Moldova, Estonia, Latvia, Lithuania, etc.) executive actions are carried out by private bailiffs who are highly qualified specialists, got university education in the field of law and passed the state qualification examination. They combine the status of representatives of a liberal profession, thus they will organize the work at their discretion, and on the other hand, they are state officials as the state delegates 
them functions to enforce judgments. Private bailiffs are appointed to the positions by public authorities by providing a licence to them. Under public models (Germany, Sweden, Finland, Austria, Spain, Denmark, Italy, Slovakia, Turkey, Croatia, Azerbaijan, Belarus, Russia, Tajikistan, etc.) enforcement of judgments is assigned only to officials of public authorities who have higher legal education and/or are prepared on special courses (it depends on the structure of body the official belongs). At the same time, courts, and specially created bodies of compulsory enforcement can be such public authorities. All public models can be divided into judicial (Austria, Denmark, Spain), non-judicial (Finland, Turkey, Sweden, Belarus) and mixed (Germany, Slovakia, Croatia) depending on the officials engaged in performance of judgments. Here officials of courts and specially created executive authorities enforce court decisions. The competence of specially created executive authorities is differentiated depending on enforcement method. Mixed models of compulsory enforcement (the USA, Kazakhstan) combine signs of private-law and public models. Under this model both public authorities and various individuals can enforce court decisions.

The system of judgments enforcement should be estimated considering their real efficiency. But forms of organization of enforcement agents' activity, that is model of court decision enforcement, do not directly define the procedure of enforcement proceedings, and in the conditions of low efficiency of enforcement proceedings it is quite appropriate to introduce mixed model of court decision enforcement, what really happened in Ukraine in 2016.

Keywords: enforcement of court decisions, models of compulsory enforcement. 